DOI: 10.20472/IAC.2019.051.043

\author{
AISWARYA THOMAS \\ INSTITUTE FOR FINANCIAL MANAGEMENT AND RESEARCH,, India
}

\title{
MONETARY POLICY INDEPENDENCE IN A MANAGED FLOATING REGIME: AN ARDL APPROACH
}

\begin{abstract}
:
Though a highly debated and contested idea, the open economy trilemma started to gain significant attention recently after Rey's argument that; in an open economy setting there is no trilemma but only a dilemma between two choices: capital mobility and independent monetary policy. In other words, Rey concludes that exchange rate regimes do not play any role in deciding between capital mobility and independent monetary policy. Further, a lot of studies have come up which largely discuss about the monetary policy independence in countries that allow free mobility of capital flows, by making comparisons between countries with fixed exchange rate regime and floating exchange rate regime. However, the studies on monetary policy independence of countries with managed floating exchange rate regimes are very scant. Given this context, it becomes quite imperative to undertake a study on the monetary policy independence in India for the fact that India is a unique case in itself with not complete free mobility of capital and a managed float exchange rate regime. . Therefore, this paper employed the auto regressive distributed lag (ARDL) approach to study the monetary policy independence in India. The results of the study reveal that the Indian monetary policy stance is highly integrated with the US and the European Union monetary policy stance.
\end{abstract}

\section{Keywords:}

Mundell's trilemma, Monetary policy Independence, Financial Integration, Globalization

JEL Classification: F41, E52, E58 